\title{
REGIONAL OPERATIONAL PROGRAM - INSTRUMENT FOR INVESTMENTS DEVELOPMENT - CENTRAL REGION, ROMANIA
}

\author{
Ionela GAVRILA-PAVEN
}

1 Decembrie 1918 University of Alba Iulia, Romania

\begin{abstract}
Maximizing the absorption of structural funds and their efficiency have to be considered in the general framework of the legislation and the economic effects generated in the national economy. The analyse presented in the article shows the results of the absorption of European funds in the financial programming period 2007-2013 for Central Region, Romania. The analyse includes also an overview on the economic evolution of the companies in sustainability period, analyse extended until 2019. European funds continue to be the main factor supporting the modernization of the Romanian economy and the implementation of structural reforms.

The analyse conducted is focused on Regional Operational Program. This program recorded one of the highest absorption rates in the financial programming period 2007-2013, having in the same time, good perspectives for the current financial programming period as well. The monitoring and implementation reports at national and regional level highlight the general program indicators, initially established and carried out during the implementation period, respectively later during their sustainability period. However, these indicators are predefined and follow the impact analysis of the Regional Operational Program at macroeconomic level. There is no information collected on the economic performance of the beneficiaries of funds under this program. This analyse naturally integrates in the area of researches that seek to bring new values, perspectives and configurations to the topic of investigating the role of the impact of non-reimbursable funds on business development. As in any scientific approach, the first step in the elaboration of research is the positioning in the sphere of knowledge, both of the general area of research and of the specific fields. The article provides also the quantitative analysis that will represent the basis for the qualitative research, which will be included in a wider analyse.

Companies that used non-reimbursable funds to support their business development, generated additional working places, increased their turn over generated through the economic activity and improved their efficiency.
\end{abstract}

Key words: structural funds, economic performance, regional development strategies

JEL Classification: L15, P17

\section{Introduction}

The pre- and post-accession experience required special attention to be paid to the process of attracting and absorbing European funds, pre-accession, and later structural and investment funds, respectively. The experience gained since Romania's integration into the European Union with full membership status, provides a broad basis on which informed and reasoned decisions can be taken in updating and adapting the national legislative framework accordingly to ensure the efficiency of absorbing European funds.

https://doi.org/10.11118/978-80-7509-820-7-0361

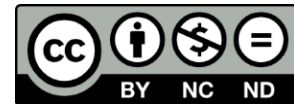


Regional development, meaning social and economic development of regions in one country but also at European Union level, is a broad concept that includes economic growth and development, and also the social changes and evolution of the communities and society in general. The background for assuring the economic development at regional level is economic growth together with social development. The regional development is being defined as a process of desirable qualitative, quantitative and structural changes in the social, cultural, economic, and infrastructure areas, which are aiming to improve the living conditions of the region's population (Sekuła, 2002; Jezierska-Thöle, 2008).

Romania, starting with the decision of integrating into the European Union, has assumed a national development policy at regional level that aims convergence with Community objectives by implementing common policies and respecting principles and regulations. This objective aims to ensure a balanced socio-economic development at regional level leading towards reducing development gaps between countries and regions at European Union (Blom-Hansen, J., 2015; Caldas, P. et al., 2018).

Balanced development inside European Union is being implemented through community policies that support all Member States through specific funds and programs, which are adjusted to the characteristics of each Member State economy (Coppola, G. et al. 2020; Crescenzi, R. et al. 2020). Romanian economy's development objectives are established at national level through National Strategic Reference Framework. Regional development includes thematic priorities and aims to support the development of basic infrastructure at European standards in order to ensure the interconnectivity of the European space (Pîrvu, R. et al. 2018; Hagemann, C., 2019).

\section{Literature review / Research Background}

Considering the economic structure, Romania has eight regions (level NUTS II). The Romanian development regions, were established based on geographic and socio-economic similarities, in order to develop coherent regional development strategies (Gavrila-Paven I., 2020). At regional level common policies and financial instruments have to ensure sustainable development, which reduces disparities between regions and can shape the development of the entire country (Wlazlak, K., 2010; Fedajev, A et al. 2019). Promoting and strengthening regional development is vital for shaping the proper conditions for the long-term development.

National investment strategies corroborated with the financial instruments which are supporting regional development have to be customized on the real needs at regional level and have to identify potential growth centres inside the regions that can support and stimulate future development. This framework can make possible to implement public tasks, especially investment project important which are proving that a long-term perspective is essential (Lewis B.D., 2011).

Regional business environment has to be encouraged and supported to increase its efficiency and competitiveness. Investment project can stimulate local development and diffuse its positive effects at regional level. But, considering from 
the coordinating possibilities from national and regional level, these expenditures may also be limited in time due to the need of covering the current ones. The essence of investment project expenditures are their real results, meaning what these projects are developing and leaving behind (UN Organisation, 2015; Heathcote, C.; Mulheirn, I., 2017). So, it is necessary to allocate funds and to use proper financial instruments for projects development as part of public spending plans.

In this framework present article is focused on the results obtained in implementing the Regional Operational Program in Romania, for Central Region.

\section{Methodology}

This study naturally integrates in the area of researchers who seek to bring new values, perspectives and configurations to the topic of investigating the role of the impact of non-reimbursable funds on business development. As in any scientific endeavour, the first step in the elaboration of research is the positioning in the sphere of knowledge, both of the general area of research and of the specific fields. Through the aspects approached, this paper belongs to the economic sciences and is part of the general area of research on the issue of sustainable development, namely the determination of the impact of the use of non-reimbursable funds on the development of enterprises. In this way, the research topic combines and even expands some elements specific to several fields of economic science, including: macroeconomics, microeconomics, management, economic and financial analysis, internal public audit, financial-accounting audit, statistics, regional development and integration European Union. The elaboration of the paper also requires a deep knowledge of national and international economic legislation in the field of management of European funds.

Overall, the scientific approach, the research methodology and perspectives will coherently combine qualitative research with quantitative research, descriptiveconceptual perspective, with empirical research. In the stage of documentation and systematization of the approaches from the specialized literature, numerous foreign and domestic specialized works, regulations and international financial reporting standards, monitoring reports made at regional and national level will be covered. The analysis of studies conducted by other researchers and the conclusions they have reached, will provide the opportunity to confirm or contradict their views and to form an overview of the issue, viewed from several points of view, precisely to eliminate subjectivism.

\section{Results}

Regional Operational Program implemented for the 2007-2013 financial period had a final level of absorption of $93.5 \%$. The investments supported through this program designated especially for the business environment continues to produce effects long after the implementation of this program. The aim of the study is to analyse these results and to observe future evolution of the business environment and to make recommendation for the present program available for 2014-2020 period 
in order to contribute to the increase of the absorption level. The Community allocation (European Regional Development Fund) available for this program in the period 2007-2013 was 3,966,021,762 euros. At the end of implementing period the stage of implementation for Regional Operational Program was as follows:

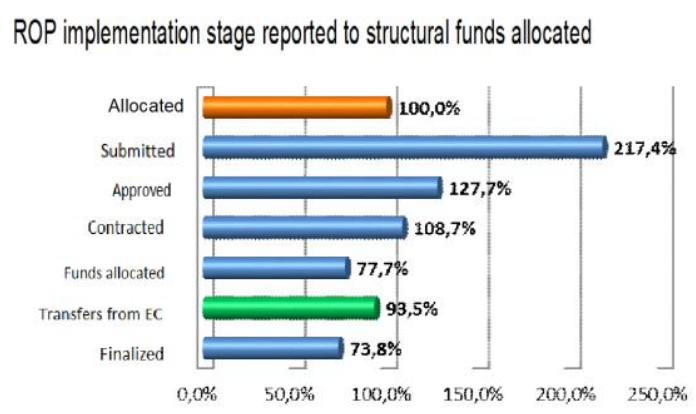

Figure 1. Regional Operational Program 2007 - 2013 implementation stage reported to structural funds allocated

Source: Evaluation Report, Interventions Evaluation ROP 2007-2013, 2019.

Global results, at national level, by implementing the 4,491 projects there were created 24,994 jobs. During the implementing period, there were 10,056 financing applications submitted overall, which requested approximatively 8.62 billion Euro contribution from the European Regional Development Fund. At the level of domains, the advance over the average of the program registered by the field of emergency equipment, micro-enterprises and social infrastructure is noticeable. 


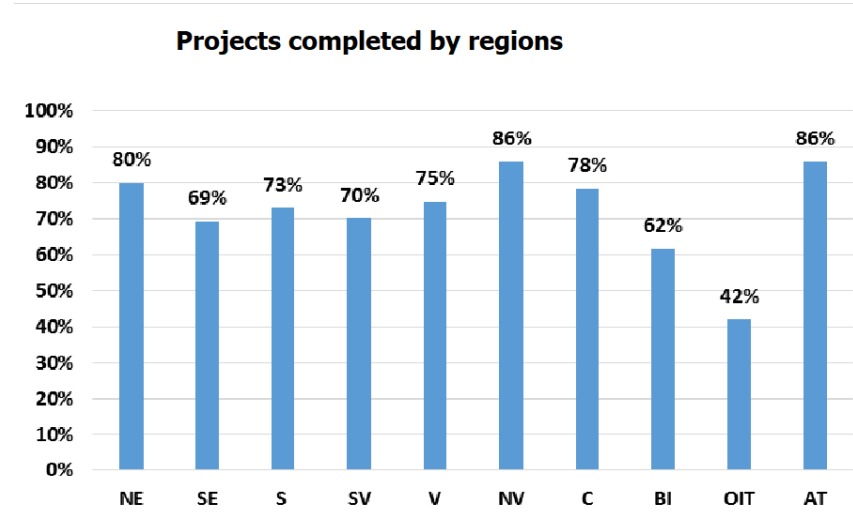

Figure 2. Completed projects implemented from Regional Operational Program 2007 - 2013 by regions at March 15, 2017

The small and medium enterprises sector remains a strategic sector for Romanian economy, including for the Central Region. The projects supported and implemented by the SMEs had the role of reducing the large differences in economic competitiveness compared to the European average in different sectors. The efforts are focused on increasing labour productivity supporting especially the investments in technology and production modernisation of the SMEs, actions that will contribute to the reducing of production costs. Also, this program represents an opportunity for SMEs to invest and support the innovation process in sectors with regional development potential. This potential has to be determined at regional level and the strategies should the designed considering these particularities. Regional Operational Program is promoting also the concept of circular economy and the involvement of SMEs in international research, development and innovation projects.

A particularly important objective of the analysis was to monitor the evolution of the survival rate of SMEs benefiting from financing instruments. The conclusion is that the resilience rate of newly created enterprises one year after the establishment is increasing from $63.4 \%$ in 2011 to $77.8 \%$ in 2015 and $68.9 \%$ in 2016, the last year with data available from the source EUROSTAT. The annual resilience rate is on an upward trend, but unsustainable in the longer term. The assessment is based on the annual volatility recorded by this indicator, respectively increases, followed by quite large decreases.

On this growth fund, instead characterized by volatility, the result indicator related to ROP, respectively the survival rate of micro-enterprises 3 years after the establishment to reach the target of $72.3 \%$ in 2023 has general favorable premises to achieve.

Both the evolution of the data from the statistical source and the assessments of the IB management factors and those responsible for monitoring and verifying the 
investment projects within the IB contribute to the shaping of these favorable premises. Thus, it is estimated that the Regional Operational Program has significantly contributed to strengthening the market position of SMEs and also to the survival rate of these enterprises. An important qualitative indication of the importance of the ROP is that during this programming period SMEs from 20072013 applied again to obtain new funds to cover their new needs.

Moreover, according to the results of the ex-post monitoring of the state aid granted in the Regional Operational Program for the period 2007-2013, very few of the financed SMEs were suspended, dissolved, deregistered or went into insolvency. All interviewees expressed optimism regarding the fulfilment of this indicator by 2023, knowing the previous efforts and the degree of awareness of the financing beneficiaries for the preservation of the project results during the state aid monitoring period.

From the perspective of the beneficiaries of financing contracts, participants in the group discussions, this effect is one pursued by their strategy of continuing to access the different types of financing available. In addition, the characteristics of the sample from the survey carried out indicate that micro-enterprises and SMEs, in their vast majority, were more than 3 years old when they submitted the projects and concluded the financing contract. It is an additional guarantee that their life expectancy due to accessing financing and solving some of the needs of endowment and recovery of the technological gap will be extended far beyond the time interval of 3 years taken in defining the result indicator.

\section{Discussion}

SMEs were considered first as a general sector that can be supported and stimulated through the allocation of Regional Operational Program. Still, although SMEs have been better integrated into the development and development of public policies, effective public policy instruments must consider the particularities of these entities. So, the instruments should be designed considering not only the size of SMEs, but also the full range of parameters that determines the nature of each SME (areas of activity, location, level of innovation) and the different phases of the life cycle of SMEs.

The good functioning of the partnership principle in the programming phase and, subsequently, in the implementation brought together in its composition representatives of all the interested parties, including of the other programs with which the Regional Operational Program is complementary. However, both the documentation carried out at the level of international practices and the field findings identified during the evaluation exercise show that there is still room for improvement in the implementation of the partnership principle during the program, as there is a risk that partner involvement was only a formalist exercise. Following these conclusions, the application of the partnership principle should be monitored during the implementation period. 
Despite the simplifications made, the lack of proportionality of administrative requirements to the amount of funding obtained is maintained, as well as other administrative obstacles that prevent SMEs from seeking support through European Structural and Investment funds. Supporting the local capacities of business support structures (consultancy services sector, territorial information and guidance centres and agencies, incubators/accelerators etc.) to assist SMEs in the process of preparation and, subsequently, implementation of their projects investment.

Depending on the category to which they belong, SMEs have distinct needs. Therefore, it had to be considered to adapt the types of support according to these different needs. Thus, the conclusion is that the Regional Operational Program proposes financing solutions based on the distinct needs of SMEs (financial instruments, venture capital fund, business incubators/accelerators, as well as supporting SME initiatives, etc.). Equally, the Regional Operational Program is only one of the financial instruments for implementing public policies to support SME development and cannot come up with financing solutions for absolutely all the problems of all SMEs in all sectors of the Romanian economy, given the intrinsic restrictions of conditioning, but and available budget.

Access to finance needs to be supported and simplified, especially for SMEs and start-ups, such as improving the training scheme, events and disseminating funding opportunities as locally as possible. This must be coupled with strengthening complementarity and synergies between Structural Funds programs and other national and $\mathrm{EU}$ investment programs.

Following the implementation of the Regional Operational Program, the service of supporting the beneficiaries was developed, so necessary during the project submission period but also during the implementation period. The support of the applicants during the clarification period during the opening of the calls also existed in the previous programming period, but the operation of this service was not in a systematic manner. This explains why there is not yet a harmonized, uniform practice in all intermediate bodies. Hence the need to improve the operational procedure, training and introduction of a mechanism for exchanging experience and lessons learned in the communication relationship with SMEs and other categories of program beneficiaries.

\section{Conclusion}

The elaboration of the 2021+ strategy for ESI funds will require a greater and more active involvement of the associative business environment of entrepreneurs' associations, employers' organizations at all levels as it was done during the Regional Operational Program preparation period or when the evolution of the growth approach concept competitiveness of SMEs required the resumption of consultations. 


\section{Acknowledgements}

This paper is part of the research conducted in the Contract for Post-Doctorate Studies, University Studies Scholarship No. 221/5 / 01.11.2019, Improving the economic and financial performance of enterprises by accessing non-reimbursable funds. Case study Regional Operational Program 2007-2013, Romanian Academy, Institute of National Economy, Bucharest, Romania.

\section{References}

1. Blom-Hansen, Jens. (2015) Principals, agents, and the implementation of EU cohesion policy. Journal of European Public Policy 12: 624-48.

2. Caldas, P., Dollery B., Cunha Marques R. (2018) European Cohesion Policy impact on development and convergence: A local empirical analysis in Portugal between 2000 and 2014. European Planning Studies 26: 1081-98.

3. Coppola, Gianluigi, Sergio Destefanis, Giorgia Marinuzzi, and Walter Tortorella. (2020) European Union and nationally based cohesion policies in the Italian regions. Regional Studies 54: 83-94.

4. Crescenzi, R., Giua M. (2020) One or many Cohesion Policies of the European Union? On the differential economic impacts of Cohesion Policy across member states, Regional Studies 54: 10-20.

5. Fedajev, A.; Nikolic, D.; Radulescu, M.; Sinisi, C.I. (2019) Patterns of structural changes in CEE economies in new millennium, Technol. Econ. Dev. Econ. 2019, 25, 1336-1362.

6. Gavrila-Paven, I. (2020) Determining International Competitiveness through Comparative Advantage at Regional Level - Instrument in Designing Regional Strategy. Study Case: Central Region, Romania, 6th BASIQ International Conference on New Trends in Sustainable Business and Consumption, Italy, pp. 618-625.

7. Hagemann, Ch. (2019) How politics matters for EU funds' absorption problems-A fuzzy-set analysis, Journal of European Public Policy 26: 188-206.

8. Heathcote, C.; Mulheirn, I. (Eds.) (2017) Global Infrastructure Outlook. In Global Infrastructure Hub, Oxford Economics: Sydney, Australia.

9. Jezierska-Thöle, A. (2008) Rozwój obszarów wiejskich Polski Pótnocnej i Zachodniej oraz Niemiec Wschodnich (Development of Rural Areas of Northern and Western Poland and Eastern Germany); Wydawnictwo Naukowe Uniwersytetu Mikołaja Kopernika: Toru 'n, Poland, 2008.

10. Lewis, B.D.; Oosterman, A. (2011) Sub-National Government Capital Spending in Indonesia: Level, Structure and Financing Public Admin. Dev. 31, 149-158.

11. Pîrvu, R., Bădîrcea R., Manta A., Lupăncescu M. (2018) The Effects of the Cohesion Policy on the Sustainable Development of the Development Regions in Romania, Sustainability 10: 2577.

12. Sekuła, A. (2002) Local Development-The Definition Aspect in the 21st Century. In Company at the Turn of the 21st Century; Politechnika Rzeszowska: Rzeszów, Poland, pp. 59-64.

13. Wlazlak, K. (2010) Rozwój regionalny jako zadanie administracji publicznej (Regional Development as a Task of Public Administration), Wolters Kluwer: Warsaw, Poland, 2010.

14. Transforming Our World: The 2030 Agenda for Sustainable Development (2015) Resolution adopted by the General Assembly on 25 September. Available online: https://www.un.org/en/development/desa/population/migration/generalassembly/docs/ globalcompact/A_RES_70_1_E.pdf (accessed on 11 June 2021). 
15. Romanian Govern, Programul Operațional Regional 2007-2013 (Regional Operational Program 2007-2013), București, 2007.

16. Romanian Govern, Programul Operațional Regional 2014-2020 (Regional Operational Program 2014-2020), București, 2015.

17. Programul Operaţional Regional 2007-2013 (Regional Operational Program 2007-2013), Raportul Final de Implementare 2007-2013 (Final Implementation Report 2007-2013), March 2017. 